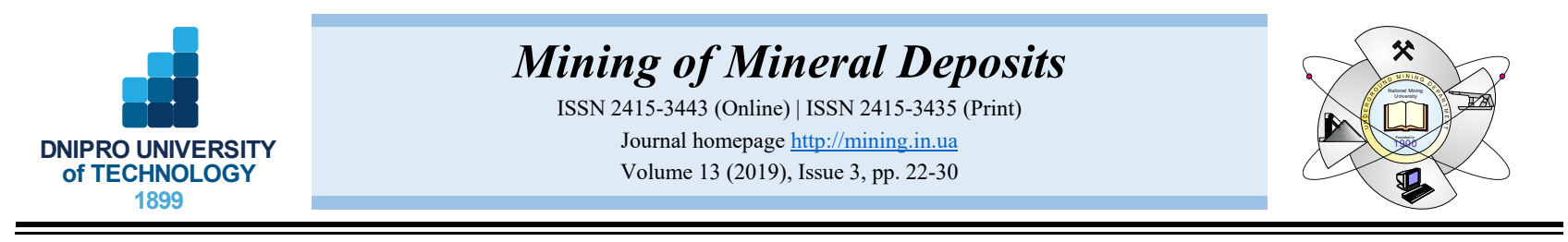

UDC 622.235.11

https://doi.org/10.33271/mining13.03.022

\title{
METHOD FOR CALCULATION OF DRILLING-AND-BLASTING OPERATIONS PARAMETERS FOR EMULSION EXPLOSIVES
}

\author{
M. Kononenko ${ }^{1 *}$, O. Khomenko ${ }^{1}$, M. Savchenko ${ }^{2}$ I. Kovalenko ${ }^{3}$ \\ ${ }^{1}$ Dnipro University of Technology, Dnipro, Ukraine \\ ${ }^{2}$ Ltd IST-FORT, Kharkiv, Ukraine \\ ${ }^{3}$ Ukrainian State University of Chemical Technology, Dnipro, Ukraine \\ *Corresponding author: e-mail kmn211179@gmail.com, tel. +380676626205
}

\begin{abstract}
Purpose. Development of a new method for calculation of drilling-and-blasting operations parameters during underground mining with application of emulsion explosives taking into account their energy characteristics as well as physical and mechanical properties of rocks.

Methods. The integrated methodological approach including analytical transformations of the received formulas for calculation of drilling-and-blasting operations parameters, their improvement and also computer modeling on the basis of a finite element method were used for the establishment of compression zones and formations of cracks in the massif around shots taking into account such energy characteristics of emulsion explosive as detonation velocity, explosion heat, density of the explosives, etc.

Findings. The relative force coefficient was determined for the emulsion explosive of "Ukrainit" type taking into account the extent of detonation velocity realization, which allowed to calculate the necessary amount of explosives. On the basis of experimental data, consistent patterns of detonation velocity change depending on the charge density and diameter yielding to power law are determined for the emulsion explosive of "Ukrainit" type. Improvements have been made to the analytical ex-pression determining the sizes of compression and fracturing zones around blast holes taking into account energy characteristics of the emulsion explosive of "Ukrainit" type as well as physical and mechanical properties of the blasted rocks. This allowed to develop a new algorithm of calculating parameters for drawing up the passport of drilling-and-blasting operations during underground mining.
\end{abstract}

Originality. The method for calculating drilling-and-blasting operations parameters is based on the regularities of emulsion explosives energy characteristics change, the extent of detonation velocity realization as well as physical and mechanical properties of rocks.

Practical implications. A new method has been developed for calculation of drilling-and-blasting operations parameters during mining with emulsion explosives application, which results in minimization of energy consumption for the mass breakage.

Keywords: drilling-and-blasting operations, emulsion explosives, explosion heat, explosive force, detonation velocity, compression and fracturing

\section{INTRODUCTION}

Drivage is one of the main production processes during the opening and preparation of the deposit for mining operations. Nowadays, up to $95 \%$ of mine workings are driven with the help of drilling-and-blasting. Therefore, special attention is paid to improvement and development of new technique for calculation of the drilling-and-blasting parameters that will provide improvement of drivage indicators and increase in safety of blasting operations. Application of various types of ex- plosives in mining led to the development of a large number of methods for calculation of drilling-andblasting parameters. However, there are no methods for accounting energy properties of emulsion explosives, which are safer, cheaper and more ecological in comparison with others (Kholodenko, Ustimenko, Pidkamenna, \& Pavlychenko, 2014). Therefore, substantiation of a new calculation procedure and drawing up passports of drilling-and-blasting operations for application of emulsion explosives are of important scientific and practical value.

(C) 2019. M. Kononenko, O. Khomenko, M. Savchenko, I. Kovalenko. Published by the Dnipro University of Technology on behalf of Mining of Mineral Deposits. This is an Open Access article distributed under the terms of the Creative Commons Attribution License (http://creativecommons.org/licenses/by/4.0/), which permits unrestricted reuse, distribution, and reproduction in any medium, provided the original work is properly cited. 
Creation and development of emulsion explosives dates back to 1961, while the early seventies of the XX century saw the creation of emulsion explosives with a critical diameter and detonation velocity corresponding to various types of dynamite (Brown, 1998). The main advantages of emulsion explosives are their low cost, fully mechanized loading and high safety in preparation and loading (Kholodenko, Ustimenko, Pidkamenna, \& Pavlychenko, 2015), absence of dangerous individual explosive components and minimum content of harmful gases in explosion products (Khomenko, Kononenko, \& Myronova, 2013). Intensive operation of deposits produces a negative impact on the environment and increases pollution levels of the atmospheric air (Myronova, 2015), water and land objects. It also results in accumulation of significant amount of industrial waste in mining regions of Ukraine (Kolesnik, Borysovs'ka, Pavlychenko, \& Shirin, 2017).

The Agreement on Association of Ukraine with the European Union stipulates implementation of the European standards and norms in the sphere of environmental protection, atmospheric air in particular. To decrease the negative impact on the environment during blasting operations, all quarries are using emulsion explosives. It is known that detonation of one kilogram of emulsion explosives is accompanied by the emission of 14 times less amount of harmful gases than during application of emulsion explosives containing trotyl. Ore mines of Ukraine use only $5 \%$ of emulsion explosives which is explained by the complexity in the development of underground mining technologies and designing charging machines for using explosives of these type (Mironova \& Borysovs'ka, 2014).

Extraction of ores is connected with drilling-andblasting operations which define efficiency of deposit mining in many respects. The high cost of industrial ammonite \#6 ZhV explosive, grammonite 79/21 and grammonite A, danger of their transportation, make it feasible to use emulsion explosives made directly on the sites of blasting operations, which ensures higher safety and smaller amount of explosion products. In conditions of the private joint stock company "Zaporizhzhia Iron Ore Plant" (PJSC “ZIOP”), emulsion explosives of "UkrainitPP" type have been used since 2008 for mining, and since the end of 2013 - for ore breaking (Khomenko, Kononenko, \& Myronova, 2017). The present research is based on physical and chemical analysis as well as biological assessment (Gorova, Pavlychenko, Borysovs'ka, \& Krups'ka, 2013) of the atmospheric air, which allowed to establish the extent of decrease in the concentration of the harmful substances emitted into the atmosphere during drilling-and-blasting operations conducted with emulsion explosives "Ukrainit-PP". Furthermore, it became possible to specify the reduction of technogenic impact on the atmospheric air and decrease of the ecological danger index to 35\% (Khomenko, Kononenko, Myronova, \& Sudakov, 2018). Application of emulsion explosives in underground mining operations is difficult not only due to the lack of charging machines, but also because of outdated method for calculation of drilling-and-blasting operation parameters which is developed for emulsion explosives containing trotyl (Kutuzov \& Andrievskiy, 2003). Thus, there is a necessity for development and implementation of a new method for calculation of drilling-and- blasting operation parameters considering energy indicators of emulsion explosives (Chernai, Sobolev, Chernai, Ilyushin, \& Dlugashek, 2003).

\section{METHOD FOR CALCULATION OF EMULSION EXPLOSIVE FORCE COEFFICIENT}

Application of various types of explosives during mining with different energy characteristics necessitates determination of force coefficient in respect to a standard reference explosive, Ammonite \#6 ZhV. However, in the known techniques, the force coefficient is determined by the indicators of force or explosion heat, which brings about considerable divergences in the calculation results, which are generally understated in the case of emulsion explosives. In this regard, it is suggested that the force coefficient for emulsion explosives should be defined considering the extent of detonation velocity realization, which allows to incorporate energy characteristics of explosives.

Ideal detonation velocity, i.e. greatest possible at the set explosive density is determined by the formula offered by the Chinese researchers (Wang, 1994):

$D_{i}=2641+3.231 \cdot \Delta \cdot \sqrt{\omega}$,

where:

$\Delta$ - charge density (explosives), $\mathrm{g} / \mathrm{cm}^{3}$;

$\omega$ - the characteristic product of explosion heat and the volume of explosion products, offered by M. Bertlo (1883) for assessment of explosive efficiency:

$\omega=Q_{\text {exp }} \cdot V_{E P}$,

where:

$Q_{\text {exp }}$ - explosion heat, $\mathrm{kkal} / \mathrm{kg}$ determined by value $Q_{e}$ $\mathrm{kJ} / \mathrm{kg}$ divided by coefficient 4.19 (mechanical equivalent of thermal energy);

$V_{E P}$ - volume of explosion products, $1 / \mathrm{kg}$.

The extent of detonation velocity realization, i.e. completeness of chemical reaction is determined by:

$\eta_{x}=\frac{D_{e}}{D_{i}} \cdot 100, \%$,

where:

$D_{e}$ - experimental detonation velocity, $\mathrm{m} / \mathrm{s}$.

Explosion heat considering the extent of detonation velocity realization:

$Q_{\text {exp }}=\frac{Q \cdot \eta_{\text {chem }}}{100}, \mathrm{~kJ} / \mathrm{kg}$,

where:

$Q$ - explosion heat of $1 \mathrm{~kg}$ of explosives, $\mathrm{kJ} / \mathrm{kg}$.

Coefficient of explosive relative force is:

$e=\frac{Q_{E T}}{Q_{E}}$,

where:

$Q_{E T}$ - explosion heat of $1 \mathrm{~kg}$ of etalon explosive (Ammonite $\# 6 \mathrm{ZhV}$ ) taking into account the extent of detonation velocity realization, $\mathrm{kJ} / \mathrm{kg}$; 
$Q_{E}$ - explosion heat of $1 \mathrm{~kg}$ of the used explosive taking into account the extent of detonation velocity realization, $\mathrm{kJ} / \mathrm{kg}$.

\section{RESULTS AND DISCUSSIONS}

We determine energy indicators for etalon explosive Ammonite \#6 ZhV explosives and "Ukrainit-P" and "Ukrainit-PP" emulsion explosives by formulas (1) - (5). The obtained results are presented in Table 1.

Table 1. Results of calculation of energy indicators

\begin{tabular}{|c|c|c|c|}
\hline Indicators & $\begin{array}{c}\text { Ammonite } \\
\# 6 \mathrm{ZhV}\end{array}$ & Ukrainit-P & Ukrainit-PP \\
\hline Density, g/cu.cm & 1.10 & 1.15 & 1.25 \\
\hline Explosion heat, $\mathrm{kcal} / \mathrm{kg}$ & 1030 & 931 & 740 \\
\hline Explosion heat, $\mathrm{kJ} / \mathrm{kg}$ & 4316 & 3900 & 3100 \\
\hline $\begin{array}{l}\text { Volume of explosion } \\
\text { products, } V_{E P}, 1 / \mathrm{kg}\end{array}$ & 895 & 890 & 847 \\
\hline $\begin{array}{l}\text { Experimental detonation } \\
\text { velocity, } D_{e}, \mathrm{~m} / \mathrm{s}\end{array}$ & 4100 & 5050 & 5100 \\
\hline $\begin{array}{l}\text { Ideal detonation } \\
\text { velocity, } D_{i}, \mathrm{~m} / \mathrm{s}\end{array}$ & 6054 & 6023 & 5838 \\
\hline $\begin{array}{l}\text { The extent of detonation } \\
\text { velocity realization, } \eta_{x}, \%\end{array}$ & 68 & 84 & 87 \\
\hline $\begin{array}{l}\text { Explosion heat taking } \\
\text { into account the extent } \\
\text { of detonation velocity } \\
\text { realization, } Q_{\text {exp }}, \mathrm{kJ} / \mathrm{kg}\end{array}$ & 2923 & 3270 & 2708 \\
\hline $\begin{array}{l}\text { Coefficient of relative } \\
\text { explosive force, } e\end{array}$ & 1.00 & 0.89 & 1.08 \\
\hline
\end{tabular}

The specific charge of explosives is determined by the universal formula of professor N. Pokrovsky (Pokrovsky, 1977):

$q=q_{1} \cdot e \cdot f_{1} \cdot k_{\text {cons }}, \mathrm{kg} / \mathrm{m}^{3}$,

where:

$q_{1}$ - normal specific charge of explosives:

$q_{1}=0.1 \cdot f, \mathrm{~kg} / \mathrm{m}^{3}$,

where:

$f$ - rock hardness coefficient;

$f_{1}$ - coefficient which considers rock structure, and for dense fine-grained rock is 0.8 , while for friable rock is 1.1 , for slate and finely fractured rock -1.3 , for viscous and porous rock -2.0 ;

$k_{\text {cons }}$ - rock constraining factor for two surfaces of exposure is $1.2-1.5$, for one surface of exposure it is determined by a formula:

$k_{\text {cons }}=\frac{6.5}{\sqrt{S_{d r}}}$,

where:

$S_{d r}$ - cross-sectional area of the working in drivage, $\mathrm{m}^{2}$.

Volume of blasted rock in the massif:

$V=S_{d r} \cdot l_{b}, \mathrm{~m}^{3}$,

where:

$l_{b}$ - blast-hole depth, $\mathrm{m}$.

Estimated amount of explosives for a face:

$Q=q \cdot V, \mathrm{~kg}$.
The arrangement of blast-holes, both in cuts, and in the face, depends on the size of least resistance line of the outside hole. Nowadays, there are many formulas allowing to define the line of least resistance of the outside hole which can conditionally be divided into two groups. Formulas of the first group, which are obtained from practical experience of blasting operations, are specified by correction coefficients. Formulas of the second group allow to define the calculated zones of rock breaking around a blast-hole charge. Therefore, the authors suggest considering formulas that are most common for computing passports of drilling-and-blasting operations because of their high accuracy and universality.

Thus, V. Shekhurdin (Shekhurdin, 1985) proposed to determine line of least resistance of the outside blast-hole by a formula which considers the amount of explosives in $1 \mathrm{~m}$ of the blast-hole and specific charge of explosives:

$W_{0}=\sqrt{\frac{p}{q \cdot m}}, \mathrm{~m}$,

where:

$m$ - the coefficient of charge convergence $0.7-1.0$, smaller value is acceptable for cutholes;

$p$-the amount of explosives placed in $1 \mathrm{~m}$ of the blast-hole, equal to:

$p=\frac{\pi \cdot d^{2}}{4} \cdot \Delta, \mathrm{kg} / \mathrm{m}$,

where:

$d$ - diameter of the blast-hole, $\mathrm{m}$;

$\Delta$ - charge density (explosives), $\mathrm{kg} / \mathrm{m}^{3}$.

S. Onika and V. Stasevich, departing from their practical experience (Onika \& Stasevich, 2005), suggest determining the line of least resistance for outside blasthole by a formula:

$W_{0}=47 \cdot K_{m} \cdot K_{c} \cdot d_{c} \cdot \sqrt{\frac{\Delta}{\gamma \cdot e}}, \mathrm{~m}$,

where:

$K_{c}$ - constraining factor, equal to 0.6 at $S_{d r}<4 \mathrm{~m}^{2}$, $0.7-0.8$ at $S_{d r}=4-60 \mathrm{~m}^{2}$ and 0.9 at $S_{d r}>60 \mathrm{~m}^{2}$;

$d_{c}$ - diameter of blasting charge, $\mathrm{m}$;

$\Delta$ - charge density (explosives), $\mathrm{t} / \mathrm{m}^{3}$;

$\gamma$ - rock density, $\mathrm{t} / \mathrm{m}^{3}$.

$K_{m}$ - coefficient of local geological conditions depending on the category of rocks fracturing (Table 2).

Table 2. Coefficients $K_{m}$ value

\begin{tabular}{lccccc}
\hline $\begin{array}{l}\text { Category of rocks } \\
\text { fracturing }\end{array}$ & I & II & III & IV & V \\
\hline $\begin{array}{l}\text { Coefficient of local } \\
\text { geological conditions, } K_{m}\end{array}$ & 1.1 & 1.05 & 1.0 & 0.95 & 0.9 \\
\hline
\end{tabular}

The long-term research conducted by A. Andrievskiy allowed to make a discovery (Andrievskiy \& Kutuzov, 1992) and develop a technique for determining line of least resistance of outside hole along the zone of rock mass fracturing around the explosive charge (Andrievskij, Avdeev, Zileev, \& Zileev, 2004). The suggested technique is based on reliable determination of radii of compression and fracturing formation zones in such sequence: 
- radius of compression zone:

$R_{s h}=d \cdot \sqrt{\frac{\rho \cdot D^{2}}{8 \cdot \sigma_{\text {comp }}}}=d \cdot \sqrt{\frac{\rho \cdot D^{2}}{8 \cdot f \cdot 10^{7}}}, \mathrm{~m}$,

where:

$d$ - diameter of charged blast-hole, $\mathrm{m}$;

$\rho-$ density of explosive in a charge, $\mathrm{kg} / \mathrm{m}^{3}$;

$D$ - detonation velocity of the applied explosive, $\mathrm{m} / \mathrm{s}$;

$\sigma_{\text {comp }}$ - ultimate compression strength, $\mathrm{Pa}$;

- radius of fracturing zone:

$R_{f r}=0.2102 \cdot d \cdot \rho^{0.75} \cdot D^{1.5} \cdot \sigma_{c o m p}^{-0.25} \cdot \tau_{c}^{-0.5}, \mathrm{~m} ;$

or:

$R_{f r}=0.7 \cdot d_{s h} \cdot \sqrt{\frac{\rho \cdot D^{2} \cdot r}{8 \cdot \tau_{c} \cdot R_{s h}}}, \mathrm{~m}$,

where:

$r$ - radius of charged blast-hole, $\mathrm{m}$;

$d_{s h}$ - diameter of compression zone, $\mathrm{m}$;

$\tau_{c}$-ultimate shear strength determined as $\tau_{c} \approx(0.02 \ldots 0.10) \cdot \sigma_{\text {comp }}, \mathrm{Pa}$;

Radius of fracturing zone is accepted as line of least resistance between outside holes, i.e. $W_{o}=R_{f r}$.

The disadvantage of the above technique is that the detonation velocity is taken in average values, which influences the accuracy of calculating the line of least resistance of outside hole. Work (Mertuszka, Cenian, Kramarczyk, \& Pytel, 2018) presents the results of the research into detonation velocity change depending on the charge diameter, but without emulsion explosives density and losses of explosive properties in time (Mertuszka \& Kramarczyk, 2018). Therefore, to optimize the technique for emulsion explosives of "Ukrainit-PP" type, we analyzed interrelations of detonation velocity, diameter of the blast-hole (borehole) and density of load. Using industrial measurement data, we plotted the graph of detonation velocity dependence on diameter of blast-hole and load density for "Ukrainit-PP" type explosive (Fig. 1) (Gorinov, Kuprin, \& Kovalenko, 2009).

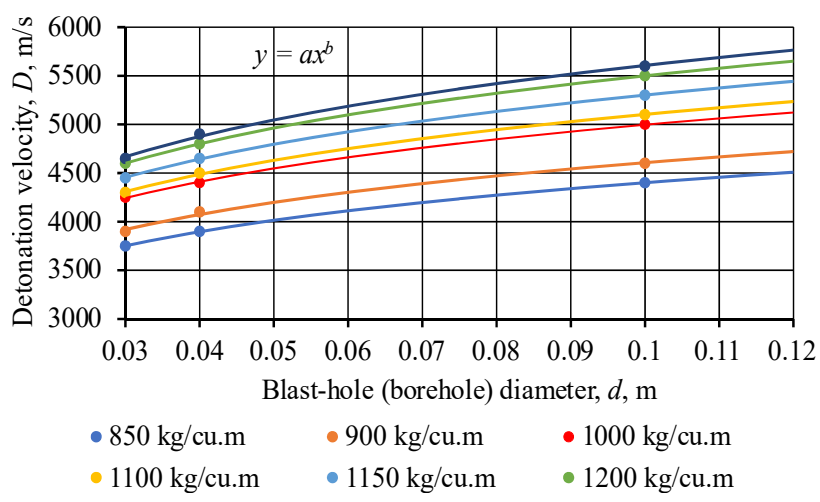

Figure 1. Detonation velocity change of "Ukrainit-PP" type explosive depending on the blast-hole (borehole) diameter and load density

Detonation velocity of "Ukrainit-PP" type explosive taking into account the influence of the blast-hole diameter and load density is determined by:
$D=(4.8 \cdot \rho+1926) \cdot d^{0.014 \sqrt[3]{\rho}}, \mathrm{m} / \mathrm{s}$.

By substituting formula (17) in expressions (14) and (15), we will receive formulas for determination of radii of compression and fracturing zones during "UkrainitPP" type explosive application:

$R_{s h}=d \cdot \sqrt{\frac{\rho \cdot\left((4.8 \cdot \rho+1926) \cdot d^{0.014 \sqrt[3]{\rho}}\right)^{2}}{8 \cdot \sigma_{c o m p}}}, \mathrm{~m} ;$

$R_{f r}=0.7 \cdot d_{s h} \cdot \sqrt{\frac{\rho \cdot\left((4.8 \cdot \rho+1926) \cdot d^{0.014 \sqrt[3]{\rho}}\right)^{2} \cdot r}{8 \cdot \tau_{c} \cdot R_{s h}}}, \mathrm{~m}$.

For checking the results convergence, we will calculate the line of least resistance for outside blast-hole using the three above techniques for the following mining-and-geological conditions: rock - ferrous quartzite, cross-sectional area of drivage $S_{d r}=12.8 \mathrm{~m}^{2}$; rock compression strength $\sigma_{\text {comp }}=140 \mathrm{MPa}$; blast-hole diameter $d=0.043 \mathrm{~m}$; rock density $\gamma=3250 \mathrm{~kg} / \mathrm{m}^{3}$; "Ukrainit-PP" type of explosive; density of explosive charge $\rho=1250 \mathrm{~kg} / \mathrm{m}^{3}$. The received results are given in Table 3 .

Table 3. Results of calculating the line of least resistance of the outside blast-hole by the analysed techniques

\begin{tabular}{cccc}
\hline Technique & V. Shekhurdin & $\begin{array}{c}\text { S. Onika, } \\
\text { V. Stasevich }\end{array}$ & A. Andrievskiy \\
\hline$W_{o}, \mathrm{~m}$ & 0.91 & 0.91 & 0.84 \\
\hline
\end{tabular}

From results of the calculation, it is evident that the divergence of least resistance lines of the outside borehole does not exceed $10 \%$. Therefore, it is possible to use any of the above techniques for its calculation. But the first two approaches do not consider energy characteristics of the applied explosives except through force coefficient of explosives rather than etalon explosives. It is offered to apply A. Andrievskiy's technique (Andrievskiy \& Avdeev, 2006) for calculating the line of least resistance of the outside blast-hole, which considers both characteristics of explosives as well as physical and mechanical properties of blasted rocks. For checking the optimized formula (18), we will execute analytical modeling of rock mass deformation (Khomenko, Kononenko, \& Petlovanyi, 2015) around the blast-hole charge in the SolidWorks Simulation software product. It is possible to simulate the rock mass compression zone around the blast-hole and further to determine fracturing formation zone radius by the formula (19). For this purpose, the program is used to build the model of the explored mass in $1: 1$ scale with the following dimensions: height $-1 \mathrm{~m}$, width $-1 \mathrm{~m}$, length $-3.5 \mathrm{~m}$ and the blast-hole diameter of $43 \mathrm{~mm}$. The $1390 \mathrm{MPa}$ pressure of explosion products of "Ukrainit-PP" explosives is set in the blast-hole. As an example, we will consider movements and deformations of rocks around the blast-hole charge during its detonation (Fig. 2) (Khomenko, Kononenko, \& Bilegsaikhan, 2018).

The analysis of simulation results has allowed to establish that rock compression zone radius was $0.18 \mathrm{~m}$. Fracturing formation zone radius, which was $0.76 \mathrm{~m}$, has been calculated by the formula (19). 
(a)

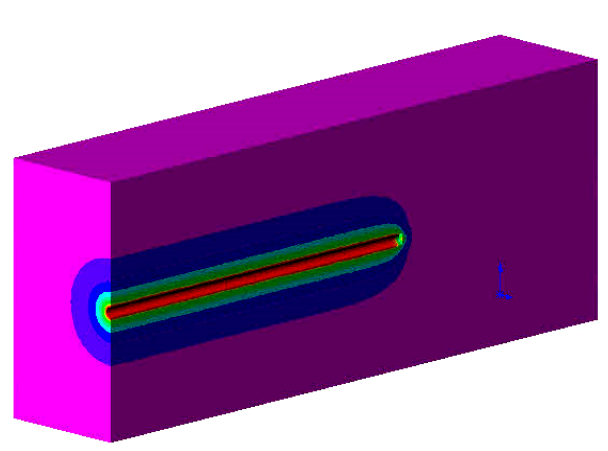

(b)

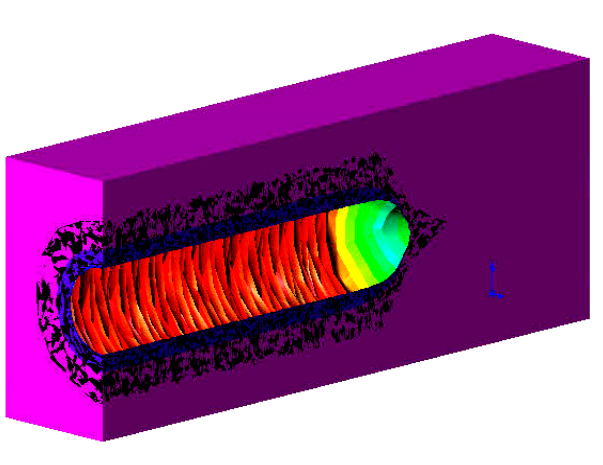

Figure 2. Areas of movement (a) and displacement with deformations (b) of rocks around the exploded blasthole charge

According to the results of comparison between numerical calculation and analytical modeling, the divergence of values has not exceeded $10 \%$. Therefore, we suggest applying A. Andrievskiy's method for calculating the line of least resistance of outside blast-hole.

After defining the line of least resistance of outside blast-hole, we proceed to calculating distances between blast-holes and start to determine their arrangement in the mine working face. Departing from the practical experience of drawing up passports of drilling-andblasting operations, the technique of blast-holes arrangement in the mine working face has been offered (Khomenko, Rudakov, \& Kononenko, 2011). The technique was based on the idea that the area of the mine working face is divided into the areas of cuthole, outside, and outline blast-holes. The area of the face, where cutholes are located, depends on the size of the face displacement behind the explosion (Table 4).

Table 4. Cuthole area

\begin{tabular}{lccccc}
\hline $\begin{array}{l}\text { Face displace- } \\
\text { ment behind } \\
\text { the explosion, } \mathrm{m}\end{array}$ & $<1.0$ & $\begin{array}{c}1.0- \\
2.0\end{array}$ & $\begin{array}{c}2.0- \\
3.0\end{array}$ & $\begin{array}{c}3.0- \\
4.0\end{array}$ & $\begin{array}{c}4.0- \\
5.0\end{array}$ \\
\hline $\begin{array}{l}\text { Cuthole area, } \\
S_{\text {cut }}, \mathrm{m}^{2}\end{array}$ & 0.45 & 0.85 & 1.25 & 1.60 & 1.95 \\
\hline
\end{tabular}

The distance from a mine working contour to outline bore-holes is used to determine the area of outline boreholes which in practice is equal to $0.15-0.25 \mathrm{~m}$ or determined by the formula (18). The distance from the line of outline bore-holes to the exfoliated surface

which is formed during detonation of outside boreholes is defined as $0.5 \cdot R_{f r}$.

The face area for outside blast-holes is:

$S_{\text {out }}=S_{d r}-\left(S_{c u t}+S_{o}\right), \mathrm{m}^{2}$,

where:

$S_{\text {cut }}$ - cuthole area, $\mathrm{m}^{2}$;

$S_{o}$ - outline blast-holes area, $\mathrm{m}^{2}$.

The number of outside blast-holes is:

$N_{\text {out }}=\frac{1.27 \cdot q \cdot S_{\text {out }}}{\Delta \cdot d^{2} \cdot k_{f u l}}, \mathrm{pcs}$,

where:

$\Delta$ - explosive density in the blast-hole or cartridge, $\mathrm{kg} / \mathrm{m}^{3}$;

$d$-diameter of the blast-hole or cartridge of the explosive, $\mathrm{m}$;

$k_{f u l}-$ coefficient of blast-hole loading, equal to $0.30-0.85$.

The received calculated number of outside blast-holes has to be analysed. Big number leads to increase in labor input and duration of drilling operations which reduces the speed of mine working drivage. On the contrary, small number of blast-holes leads to poor rock crushing by explosion which complicates its loading and transportation. The experience gained from blasting operations during mining has allowed to establish that the number of outside blastholes at which every $1 \mathrm{~m}^{2}$ of the face area has $1-2$ blastholes is optimal. A big number of blastholes indicates that the chosen explosive type was of insufficient power and the charge diameter was underated. In this case, it is necessary to use the explosive of a more powerful type, to increase the charge diameter and to recalculate blast-holes number.

The area of the face that corresponds to one outside blast-hole is:

$S_{\text {out } . b}=\frac{S_{\text {out }}}{N_{\text {out }}}, \mathrm{m}^{2}$.

The line of least resistance of outside blast-holes is:

$W_{\text {out } . b}=\sqrt{S_{\text {out } . b}}, \mathrm{~m}$.

The distance between outside blast-holes in a row is:

$a_{0}=m \cdot W_{\text {out } . b}, \mathrm{~m}$,

where:

$m$ - the coefficient of charges convergence, equal to $0.8-1.3$, smaller value of coefficient is accepted for hard rocks.

The number of outside blast-holes rows is defined as the distance from a cut to the line of outline blast-holes divided by the line of least resistance of outside blastholes which is determined by the formula (23). Optimum contours of outside blast-holes rows arrangement repeat the shape of the mine working cross section. The number of outside blast-holes in $i$-row is:

$N_{i}=\frac{P_{i}}{a_{o}}, \mathrm{~m}$,

where:

$P_{i}$ - perimeter of $i$-row of outside blast-holes, $\mathrm{m}$. 
The actual distance between outside blast-holes in $i$-row is:

$a_{i}=\frac{P_{i}}{N_{i}}, \mathrm{~m}$.

The number of outline blast-holes is:

$N_{o}=\frac{P_{o}}{a_{o}}, \mathrm{~m}$,

where:

$P_{o}-$ perimeter of outline blast-holes, $\mathrm{m}$;

$a_{o}$-distance between outline blast-holes, equal to $0.75-0.95$ from $R_{f r}$. Usually, the distance is equal to $0.75 \cdot R_{f r}$ for bottom blast-holes, for blast-holes from mine working sides $-0.95 \cdot R_{f r}$, in mine working roof $-0.85 \cdot R_{f r}$.

The actual distance between outline blast-holes is:

$a_{o}=\frac{P_{o}}{N_{o}}, \mathrm{~m}$.

Total number of blast-holes in mine working face is:

$N=N_{c u t}+N_{\text {out }}+N_{o}, \mathrm{pcs}$,

where:

$N_{\text {cut }}$ - number of outside blast-holes, pcs;

$N_{\text {out }}$ - total number of outside blast-holes, pcs.

When the drilling-and-blasting operations passport is specified, it is allowed to increase the number of blast-holes in the face by no more than $10 \%$, and in mine workings with a section up to $5 \mathrm{~m}^{2}$ - no more than by 4 blast-holes.

The blast-holes are arranged in forward, horizontal and profile projections of the face area. The arrangement of blast-holes in the face of a mine working begins with cutholes placement. If self-moving drilling equipment is used, cutholes are placed in the center of the mine working. The cut is moved closer to the bottom of the mine working to reduce scattering of rock pieces from a cuthole part. The lower boundary of the cut placement is equal to $R_{f r}$ measured from the mine working floor. Then, a contour for outline blast-holes placement is laid at the distance of $0.15-0.25 \mathrm{~m}$ or $R_{\text {sh }}$, from the working outline.

Outline blast-holes of the floor are arranged in the following sequence. First, one blast-hole is placed in each corner on the bottom line, then other floor blastholes are placed on this line in the direction to the face center maintaining the actual distance between them. Outline blast-holes on the sides are laid off the blastholes located in bottom corners of the line of the floor blast-holes. Outline blast-holes of the roof are arranged in the following sequence.

At first, one blast-hole is placed in the corners of the roof line, then other roof blast-holes are placed on this line in the direction to the face center maintaining the actual distance between them.

Outside blast-holes are arranged on the lines of the outside contours laid near the cut and parallel to the cut contour, while near the working contour - parallel to the latter. At the same time there has to be a smooth transition from one contour to another. The average value of a charge per one blast-hole is:
$Q_{b}=\frac{Q}{N}, \mathrm{~kg}$

The value of the cuthole charge is:

$Q_{c u t}=(1.1 \ldots 1.2) \cdot Q_{b}, \mathrm{~kg}$.

The value of the outside blast-hole charge is:

$Q_{\text {out }}=Q_{b}, \mathrm{~kg}$.

The value of the outline blast-hole charge from the sides and the roof is:

$Q_{o . s r}=(0.9 \ldots 0.95) \cdot Q_{b}, \mathrm{~kg}$.

The value of the outline blast-hole charge of the floor:

$Q_{o . b}=(1.0 \ldots 1.2) \cdot Q_{b}, \mathrm{~kg}$.

The actual explosive consumption on the face is:

$Q_{a c t}=N_{\text {cut }} \cdot Q_{\text {cut }}+N_{\text {out }} \cdot Q_{\text {out }}+, \mathrm{kg}$.

$+N_{o . s r} \cdot Q_{o . s r}+N_{o . b} \cdot Q_{o . b}$,

where:

$N_{o . s r}$ - the number of outline blast-holes in the roof and on the sides, pcs.;

$N_{o . b}$ - the number of outline blast-holes of the floor, pcs.

The layout arrangement is followed by the graphic presentation of a charge design for each type of blastholes and of switching network of charges.

The method for calculating drilling-and-blasting parameters can be used only during underground mining using emulsion explosives, while determination of stoping operations parameters requires modeling of compression and fracturing zones, studying the changes of emulsion explosives density and mass as well as detonation velocity along the charge length in the boreholes.

\section{CONCLUSIONS}

1. The analysis of experience related to emulsion explosives application during the last 10 years has allowed to establish a tendency for the increase in their usage in underground mining operations. Safety of operations, smaller volumes of explosion products and high power rates of emulsion explosives lead to the reduced influence on the state of the mine and atmospheric air. However, lack of the approved and widely applied methods for calculation of drilling-and-blasting operation parameters which consider energy characteristics of emulsion explosives constrain their implementation.

2. The coefficient of explosives force calculated on the basis of force or explosion heat underates up to $30 \%$ of indicators for emulsion explosives. To eliminate these disadvantages, the suggested method of calculating drilling-and-blasting operation passports defines the force coefficient considering the extent of detonation velocity realization. Calculation of drilling-and-blasting operations parameters is based on the determination of compression and fracturing formation zones around blast-hole charges. 
3. The rational arrangement of blast-holes in the face of a mine working is based on the accounting of cuts areas, breaking-off and outline parts of the face. The suggested technique of developing passports of drillingand-blasting operations is based on industrial measurements of detonation velocity during the change in density and diameters of charges of Ukrainit-PP-type emulsion explosives. The technique is recommended for calculation and drawing up passports of drilling-and-blasting operations during mining.

\section{ACKNOWLEDGEMENTS}

The authors express their deepest gratitude to V.P. Kuprin, Doctor of Philosophy in Chemistry, Professor, State Prize Laureate of Ukraine in Science and Technology for providing research base and organizational support during industrial experiments.

\section{REFERENCES}

Andrievskij, A.P., Avdeev, A.M., Zileev, G.P., \& Zileev, A.G. (2004). Influence of action time of explosion pulse of longer charge on formed explosion funnel radius. Izvestiya Vysshikh Uchebnykh Zavedenii, Gornyy Zhurnal, (2), 92-96.

Andrievskiy, A.P., \& Avdeev, A.M. (2006). Metodika opredeleniya parametrov vzryvaniya pri ochistnoy dobyche i prokhodke gornykh vyrabotok. Izvestiya Vysshikh Uchebnykh Zavedeniy. Gornyy Zhurnal, (6), 60-65.

Andrievskiy, A.P., \& Kutuzov, B.N. (1992). Zakonomernost' formirovaniya zon smyatiya $i$ treshchinoobrazovaniya pri vozdeystvii na skal'nyy massiv energiey vzryva udlinennogo zaryada: otkrytie. Otkrytie No. 70. Moskva, Rossiya.

Brown, G.I. (1998). The big bang: a history of explosives. Stroud, United Kingdom: Sutton Pub Ltd.

Chernai, A.V., Sobolev, V.V., Chernai, V.A., Ilyushin, M.A., \& Dlugashek, A. (2003). Laser ignition of explosive compositions based on di-(3-hydrazino-4-amino-1,2,3-triazole)copper (II) perchlorate. Combustion, Explosion and Shock Waves, 39(3), 335-339.

Gorinov, S.A., Kuprin, V.P., \& Kovalenko, I.L. (2009). Evaluation of the detonation ability emulsion explosives. High Energy Materials Processing, 18-26.

Gorova, A., Pavlychenko, A., Borysovs'ka, O., \& Krups'ka, L. (2013). The development of methodology for assessment of environmental risk degree in mining regions. Annual Scientific-Technical Collection - Mining of Mineral Deposits 2013, 207-209. https://doi.org/10.1201/b16354-38

Kholodenko, T., Ustimenko, Y., Pidkamenna, L., \& Pavlychenko, A. (2014). Ecological safety of emulsion explosives use at mining enterprises. Progressive Technologies of Coal, Coalbed Methane, and Ores Mining, 255-260. https://doi.org/10.1201/b17547-45

Kholodenko, T., Ustimenko, Y., Pidkamenna, L., \& Pavlychenko, A. (2015). Technical, economic and environmental aspects of the use of emulsion explosives by ERA brand in underground and surface mining. New Developments in Mining Engineering 2015: Theoretical and Practical Solutions of Mineral Resources Mining, 211-219. https://doi.org/10.1201/b19901-38

Khomenko, O.Y., Kononenko, M.M., Myronova, I.G., \& Sudakov, A.K. (2018). Increasing ecological safety during underground mining of iron-ore deposits. Naukovyi Visnyk Natsionalnoho Hirnychoho Universytetu, (2), 29-38. https://doi.org/10.29202/nvngu/2018-2/3
Khomenko, O., Kononenko, M., \& Bilegsaikhan, J. (2018). Classification of theories about rock pressure. Solid State Phenomena, (277), 157-167. https://doi.org/10.4028/www.scientific.net/ssp.277.157

Khomenko, O., Kononenko, M., \& Myronova, I. (2013). Blasting works technology to decrease an emission of harmful matters into the mine atmosphere. Annual Scientific-Technical Collection - Mining of Mineral Deposits 2013, 231-235.

https://doi.org/10.1201/b16354-43

Khomenko, O., Kononenko, M., \& Myronova, I. (2017). Ecological and technological aspects of iron-ore underground mining. Mining of Mineral Deposits, 11(2), 59-67. https://doi.org/10.15407/mining11.02.059

Khomenko, O., Kononenko, M., \& Petlovanyi, M. (2015). Analytical modeling of the backfill massif deformations around the chamber with mining depth increase. New Developments in Mining Engineering 2015: Theoretical and Practical Solutions of Mineral Resources Mining, 265-269. https://doi.org/10.1201/b19901-47

Khomenko, O., Rudakov, D., \& Kononenko, M. (2011). Automation of drill and blast design. Technical and Geoinformational Systems in Mining, 271-275. https://doi.org/10.1201/b11586-45

Kolesnik, V.Ye., Borysovs'ka, O.O., Pavlychenko, A.V., \& Shirin, A.L. (2017). Determination of trends and regularities of occurrence of emergency situations of technogenic and natural character in Ukraine. Naukovyi Visnyk Natsionalnoho Hirnychoho Universytetu, (6), 124-131.

Kutuzov, B.N., \& Andrievskiy, A.P. (2003). Novaya teoriya $i$ novye tekhnologii razrusheniya gornykh porod udlinennymi zaryadami vzryvchatykh veshchestv. Novosibirsk, Rossiya: Nauka.

Mertuszka, P., \& Kramarczyk, B. (2018). The impact of time on the detonation capacity of bulk emulsion explosives based on Emulinit 8L. Propellants, Explosives, Pyrotechnics, 43(8), 799-804. https://doi.org/10.1002/prep.201800062

Mertuszka, P., Cenian, B., Kramarczyk, B., \& Pytel, W. (2018). Influence of explosive charge diameter on the detonation velocity based on Emulinit 7L and 8L bulk emulsion explosives. Central European Journal of Energetic Materials, 15(2), 351-363.

https://doi.org/10.22211/cejem/78090

Mironova, I., \& Borysovs'ka, O. (2014). Defining the parameters of the atmospheric air for iron ore mines. Progressive Technologies of Coal, Coalbed Methane, and Ores Mining, 333-339.

https://doi.org/10.1201/b17547-57

Myronova, I. (2015). The level of atmospheric pollution around the iron-ore mine. New Developments in Mining Engineering 2015: Theoretical and Practical Solutions of Mineral Resources Mining, 193-197. https://doi.org/10.1201/b19901-35

Onika, S.G., \& Stasevich, V.I. (2005). Razrushenie gornykh porod vzryvom. Minsk: BNTU.

Pokrovsky, N.M. (1977). Underground structures and mines construction practices. Nairobi, Kenya: University of Nairobi.

Shekhurdin, V.K. (1985). Zadachnik po gornym rabotam, provedeniyu i krepleniyu gornykh vyrabotok.

Wang, X. (1994). Emulsion explosives. Beijing, China: Metallurgical Industry Press. 


\section{МЕТОДИКА РОЗРАХУНКУ ПАРАМЕТРІВ БУРОПІДРИНИХ РОБІТ ДЛЯ ЕМУЛЬСІЙНИХ ВИБУХОВИХ РЕЧОВИН}

\section{М. Кононенко, О. Хоменко, М. Савченко, І. Коваленко}

Мета. Розробка нової методики розрахунку параметрів буропідривних робіт (БПР) при проведенні підземних гірничих виробок із використанням емульсійних вибухових речовин (EBP) з урахуванням їх енергетичних характеристик і фізико-механічних властивостей порід.

Методика. У роботі використано комплексний методичний підхід, що включає аналітичні перетворення раніше отриманих формул розрахунку параметрів БПР та їх удосконалення, а також комп’ютерне моделювання на основі методу скінчених елементів зі встановлення зон зминання та утворення тріщин в масиві навколо шпурів з урахуванням енергетичних характеристик емульсійної вибухівки: швидкість детонації, теплота вибуху, щільність вибухових речовин (ВР) та ін.

Результати. Визначено коефіцієнт відносної працездатності емульсійної вибухівки типу "Україніт" 3 урахуванням ступеня реалізації швидкості детонації, що дозволило визначити необхідну кількість ВР. На основі експериментальних даних встановлено закономірності зміни швидкості детонації від щільності та діаметру заряду для ЕВР типу “Україніт”, які змінюються за ступеневим законом. Удосконалено аналітичний вираз, що визначає розміри зон зминання та тріщин, які утворюються навколо шпурів з урахуванням енергетичних характеристик ЕВР “Україніт" і фізико-механічних властивостей порід, на чому грунтується подальший вдосконалений алгоритм розрахунку параметрів для складання паспорта БПР при проведенні підземних гірничих виробок.

Наукова новизна. Полягає у використанні закономірностей зміни енергетичних властивостей ЕВР, ступеня реалізації швидкості детонації та фізико-механічних властивостей гірських порід при розробці методики розрахунку параметрів БПР.

Практична значимість. Розроблено нову методику розрахунку параметрів БПР при проведенні гірничих виробок на основі використання EBP, що забезпечує мінімізацію енергетичних витрат на руйнування масиву.

Ключові слова: буропідривні роботи, емульсійні вибухові речовини, теплота вибуху, прачездатність вибухових речовин, швидкість детонації, зминання та утворення тріщин

\section{МЕТОДИКА РАСЧЕТА ПАРАМЕТРОВ БУРОВЗРЫВНЫХ РАБОТ ДЛЯ ЭМУЛЬСИОННЫХ ВЗРЫВЧАТЫХ ВЕЩЕСТВ}

\section{М. Кононенко, О. Хоменко, Н. Савченко, И. Коваленко}

Цель. Разработка новой методики расчета параметров буровзрывных работ (БВР) при проведении подземных горных выработок с использованием эмульсионных взрывчатых веществ (ЭВВ) с учетом их энергетических характеристик и физико-механических свойств пород.

Методика. В работе использован комплексный методический подход, включающий аналитические преобразования ранее полученных формул расчета параметров БВР и их усовершенствование, а также компьютерное моделирование на основе метода конечных элементов по установлению зон смятия и образования трещин в массиве вокруг шпуров с учетом энергетических характеристик ЭВВ: скорость детонации, теплота взрыва, плотность взрывчатых веществ (ВВ) и др.

Результаты. Определен коэффициент относительной работоспособности ЭВВ типа "Украинит" с учетом степени реализации скорости детонации, что позволило определить необходимое количество ВВ. На основе экспериментальных данных установлены закономерности изменения скорости детонации от плотности и диаметра заряда для ЭВВ типа "Украинит", которые изменяются по степенному закону. Усовершенствовано аналитическое выражение, определяющее размеры зон смятия и трещинообразования, образуемых вокруг шпуров с учетом энергетических характеристик ЭВВ "Украинит" и физико-механических свойств взрываемых пород, на чем основывается дальнейший усовершенствованный алгоритм расчета параметров для составления паспорта БВР при проведении подземных горных выработок.

Научная новизна. Состоит в использовании закономерностей изменения энергетических характеристик ЭВВ, степени реализации скорости детонации и физико-механических свойств горных пород при разработке методики расчета параметров БВР.

Практическая значимость. Разработана новая методика расчета параметров БВР при проведении горных выработок на основе использования ЭВВ, обеспечивающая минимизацию энергетических затрат на разрушение массива.

Ключевые слова: буровзрывные работы, эмульсионные взрывчатые вещества, теплота взрыва, работоспособность взрывчатых веществ, скорость детонации, смятие и трещинообразование

\section{ARTICLE INFO}

Received: 16 October 2018

Accepted: 28 June 2019

Available online: 4 July 2019 


\section{ABOUT AUTHORS}

Maksym Kononenko, Candidate of Technical Sciences, Associate Professor of the Underground Mining Department, Dnipro University of Technology, 19 Yavornytskoho Ave., 49005, Dnipro, Ukraine. E-mail: kmn211179@gmail.com

Oleh Khomenko, Doctor of Technical Sciences, Professor of the Underground Mining Department, Dnipro University of Technology, 19 Yavornytskoho Ave., 49005, Dnipro, Ukraine. E-mail: rudana.in.ua@gmail.com

Mykola Savchenko, Candidate of Technical Sciences, Laureate of State Prize of Ukraine in Science and Technology, Ltd IST-FORT, 4 Kaplunivskyi Alley, 61000, Kharkiv, Ukraine. E-mail: baksnv1@gmail.com

Ihor Kovalenko, Doctor of Technical Sciences, Professor of the Inorganic Chemistry Department, Ukrainian State University of Chemical Technology, 8 Haharina Ave., 49005, Dnipro, Ukraine. E-mail: il.kovalenko050@gmail.com 